\title{
Comparative Study of Energy Use Pattern of Conventional Farming and Organic Farming in Rice Production in Visakhapatnam District of Andhra Pradesh State
}

\author{
S. Shrine* and K. Umadevi \\ Department of Agricultural Economics, Agricultural College, Acharya N. G. Ranga \\ Agricultural University, Bapatla, India \\ *Corresponding author
}

\section{A B S T R A C T}

\section{Keywords}

Conventional

Farming,

Organic Farming

Article Info

Accepted:

12 November 2020

Available Online:

10 December 2020
The study examined the energy use pattern of conventional farming and organic farming in rice production in Visakhapatnam district. Fertilizer was found to be the dominant source of energy in both farming methods of rice production. The total energy utilized for rice production was highest in conventional farming compared to organic farming. The energy use efficiency was highest in organic farming than conventional farming.

\section{Introduction}

The important sector in Indian economy is the agriculture and it is one of the most energy consuming economies. During 2017-18, rice production in India was 111.01 million tonnes and in India, Andhra Pradesh ranks $5^{\text {th }}$ in rice production. In Andhra Pradesh, rice is cultivated in 22.18 lakh hectares and production and productivity were about 126.91 lakh tonnes and $5722 \mathrm{~kg} \mathrm{ha}^{-1}$ (201718) respectively. In Andhra Pradesh, Visakhapatnam district has a production of 3.43 lakh tonnes in 109 thousand hectares. In India, the rice is cultivated in different farming methods such as conventional farming, organic farming, zero budget natural farming etc., The energy use pattern for rice crop has varied under different farming methods. The use of energy in crop production depends on the availability of energy sources and capacity of farmers.

Conventional farming refers to farming systems which include the use of synthetic chemical fertilizers, pesticides, herbicides and other inputs, genetically modified organisms, concentrated animal feeding operations, heavy irrigation and intensive tillage. Organic farming involves cultivation of crop using biological materials, avoiding synthetic substances to maintain soil fertility and 
ecological balance. The energy consumption varies from each other in both farming methods. It is invested in various forms such as mechanical power, human labour, animal draft, fertilizer, pesticides etc. Ploughing consumed highest amount of energy which accounted to 20.58 per cent of the total energy utilized for all operations in paddy cultivation (Kumar and Hugar, 2011). Sufficient availability of the right energy and its effective and efficient use are prerequisites for improved agricultural production It was realized that crop yields and food supplies are directly linked to energy (Stout, 1990).

Energy is invested in various forms such as mechanical power, human labour, animal draft chemical fertilizer, pesticides, herbicides etc., So, the present study is based on energy consumption in two different farming methods in rice production.

\section{Materials and Methods}

The present study was carried out in Visakhapatnam district of Andhra Pradesh (AP) state during 2017-18. A multi- stage random sampling method was adopted for the selection of mandals, villages and farmers. In first stage, four mandals namely, Anakapalle, Chodavaram, Paderu, Hukumpeta were selected in Visakhapatnam district, as the farmers were practicing conventional farming in Anakapalle and Chodavaram mandals and Organic farming in Paderu and Hukumpeta mandals. In second stage, two villages from each mandal were selected based on the maximum number of farmers practicing three farming methods. In third stage, a total sample size of 109 respondents out of 625 was selected based on Cochran's formula for the present study. The respondents following conventional farming and organic farming were selected based on the proportional total.

$$
\mathrm{n}_{0}=\frac{z^{\mathrm{x}} \mathrm{pq}}{\mathrm{e}^{\mathrm{z}}}
$$

$\mathrm{n}=\frac{\frac{n_{0}}{1+\frac{n_{0}-1}{N}}}{\frac{n^{\prime}}{N}}$

Where, $n=$ sample population

$\mathrm{N}=$ Total population

$\mathrm{Z}=$ Critical value

$\mathrm{e}=$ sampling error

$\mathrm{p}=0.5, \mathrm{q}=1-0.5$

Inputs and output energy was calculated by converting physical units of inputs and outputs into respective energy units by using appropriate energy equivalents presented in Table 2 to find out the energy use pattern.

Agriculture is not only a consumer of energy but also a producer of energy in the form of output. The efficiency of energy can be calculated by ratio of output energy to input energy.

Energy productivity $=$ Rice output $\left(\mathrm{Kg} \mathrm{ha}^{-1}\right) /$ Energy input (MJ ha $\left.{ }^{-1}\right)$

Specific energy $=$ Energy input $\left(\mathrm{MJ} \mathrm{ha}^{-1}\right) /$ Rice output $\left(\mathrm{Kg} \mathrm{ha}^{-1}\right)$

Net energy= Energy output $\left(\mathrm{MJ}_{\mathrm{ha}}{ }^{-1}\right)$ - Energy input $\left(\mathrm{MJ} \mathrm{ha}^{-1}\right)$

Energy intensiveness $=$ Energy input $\left(\mathrm{MJ} \mathrm{ha}^{-}\right.$

$\left.{ }^{1}\right) /$ Cost of cultivation $\left(\mathrm{Rs} \mathrm{ha}^{-1}\right)$

Energy use efficiency $=$ Energy output $\left(\mathrm{MJ}_{\mathrm{H}}{ }^{-}\right.$ $\left.{ }^{1}\right) /$ Energy input $\left(\mathrm{MJ} \mathrm{ha}^{-1}\right)$

\section{Results and Discussion}

The total operation- wise energy consumption in organic farming was $13978.84 \mathrm{MJ} / \mathrm{ha}$. Among all the inputs, organic fertilizers and manures (8823.42 MJ/ha.) consumed highest energy farming followed by human (1332.90 $\mathrm{MJ} / \mathrm{ha}$.), machinery (1322.12 MJ/ha.), seed (1089.00 MJ/ha.), biocides (940.06 MJ/ha.) and animal (471.34 MJ/ha.) (Table 1-4). 
Table.1 Sampling frame of respondents

\begin{tabular}{|c|l|l|c|c|c|c|}
\hline S. No. & Mandals & Villages & $\begin{array}{c}\text { Population } \\
\text { size }\end{array}$ & $\begin{array}{c}\text { Per cent to } \\
\text { total } \\
\text { population }\end{array}$ & $\begin{array}{c}\text { Sample } \\
\text { size }\end{array}$ & $\begin{array}{c}\text { Per cent } \\
\text { to total } \\
\text { sample }\end{array}$ \\
\hline \multirow{2}{*}{ 1. } & Anakapalle & Dibbapalem & 102 & 13.04 & 18 & 13.04 \\
\hline & & Venkupalem & 98 & 12.53 & 17 & 12.53 \\
\hline \multirow{2}{*}{ 2. } & Chodavarm & Narsapuram & 104 & 13.29 & 18 & 13.29 \\
\hline & & Lakshmipum & 92 & 11.76 & 16 & 11.76 \\
\hline \multirow{2}{*}{ 3. } & Paderu & Thumpada & 22 & 2.81 & 4 & 2.81 \\
\hline \multirow{2}{*}{} & 4. & Vanajangi & 57 & 7.28 & 10 & 7.28 \\
\hline & Hukumpeta & Rangasheela & 92 & 11.76 & 16 & 11.76 \\
\hline & Bodigaputtu & 58 & 7.41 & 10 & 7.41 \\
\hline & TOTAL & & 625 & & 109 & \\
\hline
\end{tabular}

Table.2 Energy equivalents of different inputs and outputs

\begin{tabular}{|c|c|c|c|}
\hline S. NO. & ENERGY SOURCE & UNITS & $\begin{array}{c}\text { ENERGY } \\
\text { EQUIVALENTS (MJ) }\end{array}$ \\
\hline A. & Inputs & & \\
\hline 1. & $\begin{array}{l}\text { Human labour } \\
\text { A. Man } \\
\text { B. Woman }\end{array}$ & $\begin{array}{l}\mathrm{h} \\
\mathrm{h}\end{array}$ & $\begin{array}{l}1.96 \\
1.57\end{array}$ \\
\hline 2. & $\begin{array}{l}\text { Animal labour } \\
\text { A. Bullocks }\end{array}$ & Pair- hour & 10.10 \\
\hline 3. & Machine labour & $\mathrm{H}$ & 62.70 \\
\hline 4. & $\begin{array}{l}\text { Fertilizers } \\
\text { A. Nitrogen } \\
\text { B. Phosphorous } \\
\text { C. Potash } \\
\text { D. Sulphur }\end{array}$ & $\begin{array}{l}\mathrm{kg} \\
\mathrm{kg} \\
\mathrm{kg} \\
\mathrm{kg}\end{array}$ & $\begin{array}{c}66.44 \\
12.44 \\
11.15 \\
1.20\end{array}$ \\
\hline 7. & $\begin{array}{l}\text { Organic fertilizers } \\
\text { Farmyard manure } \\
\text { Commercial compost } \\
\text { Green manure } \\
\text { Bio- fertilizers }\end{array}$ & $\begin{array}{l}\mathrm{kg} \\
\mathrm{kg} \\
\mathrm{kg}(\text { seed }) \\
\mathrm{L}\end{array}$ & $\begin{array}{c}0.33 \\
10.50 \\
15.90 \\
2.98\end{array}$ \\
\hline 8. & $\begin{array}{l}\text { Chemicals } \\
\text { A. Herbicides } \\
\text { B. Pesticides } \\
\text { C. Fungicide }\end{array}$ & $\begin{array}{l}\mathrm{kg} \\
\mathrm{kg} \\
\mathrm{kg}\end{array}$ & $\begin{array}{c}238.00 \\
199.00 \\
92.00\end{array}$ \\
\hline 9. & $\begin{array}{l}\text { Bio- fungicide } \\
\text { Bio- insecticides }\end{array}$ & $\begin{array}{l}\mathrm{L} \\
\mathrm{L}\end{array}$ & $\begin{array}{l}10.10 \\
21.60\end{array}$ \\
\hline 10. & Seeds & $\mathrm{Kg}$ & 14.70 \\
\hline \multirow[t]{2}{*}{ B. } & Output & & \\
\hline & Rice & $\mathrm{Kg}$ & 17.00 \\
\hline
\end{tabular}

$\mathrm{L}=$ Litres, $\mathrm{kg}=$ Kilogram, $\mathrm{h}=$ hour

Source: Sefeedpariet al. (2012), Bilaliset al. (2013) 
Table.3 Energy use pattern of rice production $\left(\mathrm{MJ} \mathrm{ha}^{-1}\right)$

\begin{tabular}{|c|c|c|c|c|}
\hline \multirow{2}{*}{$\begin{array}{c}\text { Particulars } \\
\text { Inputs }\end{array}$} & \multicolumn{2}{|c|}{ Conventional farming $(\mathrm{N}=69)$} & \multicolumn{2}{|c|}{ Organic Farming $(\mathrm{N}=40)$} \\
\hline & $\begin{array}{c}\text { Energy } \\
\text { (MJ/ha.) }\end{array}$ & Per centage & $\begin{array}{l}\text { Energy } \\
\text { (MJ/ha.) }\end{array}$ & Per centage \\
\hline Human & 1778.42 & 7.71 & 1332.9 & 9.53 \\
\hline Machine & 4552.46 & 19.74 & 1322.12 & 9.45 \\
\hline Animal & - & - & 471.34 & 3.37 \\
\hline Seed & 1046.37 & 4.53 & 1089.00 & 7.79 \\
\hline $\begin{array}{c}\text { Natural } \\
\text { fertilizers and } \\
\text { manures }\end{array}$ & - & & - & - \\
\hline $\begin{array}{c}\text { Chemical } \\
\text { fertilizers and } \\
\text { manures }\end{array}$ & 15351.87 & 66.58 & - & - \\
\hline $\begin{array}{c}\text { organic } \\
\text { fertilizers and } \\
\text { manures }\end{array}$ & - & - & 8823.42 & 63.11 \\
\hline $\begin{array}{c}\text { Plant } \\
\text { protection } \\
\text { chemicals }\end{array}$ & 326.48 & 1.41 & - & - \\
\hline Biocides & - & - & 940.06 & 6.72 \\
\hline Total & 23055.6 & 100 & 13978.84 & 100.00 \\
\hline \multicolumn{5}{|l|}{ Output } \\
\hline Yield & 64771.87 & & 75796.87 & \\
\hline
\end{tabular}

Table.4 Energy indices for rice production

\begin{tabular}{|l|c|c|}
\hline Parameter & Conventional farming & Organic farming \\
\hline Energy productivity $\left(\mathbf{k g ~ M J}^{-\mathbf{1}}\right)$ & 0.17 & 0.38 \\
\hline Specific energy $\left(\mathbf{M J ~ k g} \mathbf{~ k g}^{-1}\right)$ & 5.57 & 2.63 \\
\hline Net energy $\left(\mathbf{M J} \mathbf{~ h a}^{-1}\right)$ & 47468.63 & 60683.019 \\
\hline Energy use efficiency & 3.05 & 5.27 \\
\hline
\end{tabular}

In two different farming methods for rice production, conventional farming consumed maximum amount of energy (23055.6 MJ/ha.) compared to organic farming (13978.84 $\mathrm{MJ} / \mathrm{ha}$.). Among all the operations in two different farming methods, fertilizer and manures consumed maximum amount of energy. These findings are in line with the findings of Pradhan et al., (2015) who reported that fertilizer consumed highest amount of energy in rice production. The maximum yield energy estimated for rice production was in organic farming (75796.87 $\mathrm{MJ} / \mathrm{ha}$.) compare to conventional farming (64771.87 MJ/ha.).

From Table 4, in conventional farming, the energy productivity was found to be 0.17 $\mathrm{kg} / \mathrm{MJ}$. That means $0.17 \mathrm{~kg}$ grain output was obtained per unit energy. The specific energy was found to be $5.57 \mathrm{MJ} / \mathrm{kg}$. Initiating that, to produce one $\mathrm{kg}$ of grain output 5.57 MJ 
energy was consumed. The net energy was found to be $47468.63 \mathrm{MJ} \mathrm{ha}^{-1}$. The energy use efficiency was found to be 3.05 which indicates the efficiency of rice production.

In organic farming, the energy productivity was found to be $0.38 \mathrm{~kg} / \mathrm{MJ}$. That means $0.38 \mathrm{~kg}$ grain output was obtained per unit energy. The specific energy was found to be $2.63 \mathrm{MJ} / \mathrm{kg}$. That means, to produce one $\mathrm{kg}$ of grain output $2.63 \mathrm{MJ}$ energy was consumed. The net energy was found to be 60683.019 $\mathrm{MJ} \mathrm{ha}^{-1}$. The energy use efficiency was found to be 5.27 which indicate the efficiency of rice production.

The energy use efficiency was found to be higher in organic farming compared to conventional farming because in organic farming, less input energy was consumed per unit output energy. The net energy was found to be high in organic farming than conventional farming.

In conclusion, the total energy consumption was highest in conventional farming compared to organic farming. The difference in energy consumption is mainly due to (chemical/organic) fertilizers and manures in the two farming methods. The energy use efficiency is highest in organic farming compared to conventional farming. The net energy was found to be high in organic farming compared to conventional farming.

\section{References}

Kumar, P.P.S and Hugar, L.B. 2011. Economic analysis of energy use in paddy cultivation under irrigated situations. Karnataka Journal of Agricultural Sciences. 24(4):467-470.

Stout, B. A. 1990. Handbook of Energy for World Agriculture. Elsevier Applied Science, London.

Sefeedpari, P., Rafiee, S., Komleh, S. H. P and Ghahderijani, Md. 2013. A sourcewise and operationwise energy use analysis for corn silage production, a case study of Tehran province, Iran. International Journal of Sustainable Built Environment. 1: 158- 166.

Bilalis, D., Kamariari, P. E., Karkanis, A., Efthimiadou, A., Zorpas, A and Kakabouki, L. 2013. Energy inputs, output and productivity in organic and conventional maize and tomato production, under Mediterranean conditions.

NotulaeBotanicaeHortiAgrobotanici Cluj-Napoca. 41 (1): 190- 194.

Pradhan, P., Naik, R.K., Manisha sahu and Cholesh, T. 2015. A study on the energy use pattern and cost of production under transplanted paddy production system in Chhattisgarh, India. International Journal of Engineering Research \& Technology. 4 (7): 1014-1018.

\section{How to cite this article:}

Shrine, S. and Umadevi, K. 2020. Comparative Study of Energy Use Pattern of Conventional Farming and Organic Farming in Rice Production in Visakhapatnam District of Andhra Pradesh State. Int.J.Curr.Microbiol.App.Sci. 9(12): 1505-1509. doi: https://doi.org/10.20546/ijcmas.2020.912.179 